\title{
北京における歴史的環境保全制度の変遷並びに現在の構成 THE FORMATION PROCESS OF THE HISTORICAL ENVIRONMENT CONSERVATION SYSTEM AND IT'S PRESENT STRUCTURE IN BEIJING
}

\author{
銭威*, 岡崎篤行** \\ Wei QIAN and Atsuyuki OKAZAKI
}

\begin{abstract}
This research takes one of the most important Chinese cultural city and the Chinese capital, Beijing, as an object of study. We grasped the formation process of the historical environment conservation system and made clear it's present structure. From the development of the conservation system on regulation,planning and projects, we divided the formation process into five periods and grasped the special feature of every period. Especially, we analyzed the problems of the conservation system on historical cultural city,conservation districts, historical relics and architectures that have certain degree of historical values.Finally, the relationship of governments,citizens and specialists was made clear.
\end{abstract}

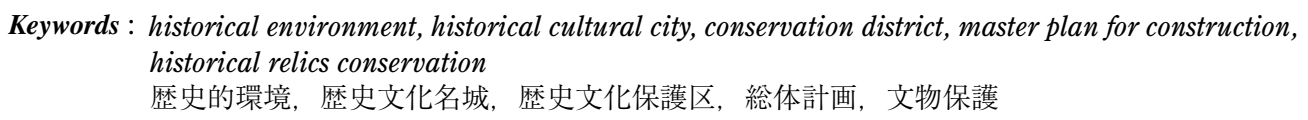

\section{1 研究の背景と目的}

1982 年より、中国各都市の急激な都市再開発事業や旧市街地の歴 史的景観の大きな変容に対して、国レベルの保全制度として国家歴 史文化名城（以下名城）制度が発足した。しかし、様々な特徽を持 つ歴史地区の保全や整備などに充分な対応ができず、柔軟性が低い などの問題点があったと言われている1'。このため、1986 年に第2 回 名城指定が行われた際に、歴史保全地域を都市開発地域から分離さ せて集中的に保存できるように「歷史文化保護区」（以下保護区に略

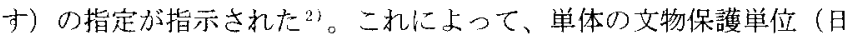
本の重要文化財に相当)、保全地区、都市全体という「三層」の保全 体系が形成され、全国各地で展開されることとなっだ”。

首都である北京では、2008 年のオリンピックに向け、90 年代末加 ら旧城内での再開発が加速し、歴史的環境の保全は最大の危機を迎 えている注2!。これらを改善するため、近年、北京の歷史的環境の特 徴に応じて一連の保全制度が作成されているが、地区整備による伝 統建築の取り壊しや強制的な住民移転による住民の不満等多くの問 題を残している。そのため、まず、保全制度の発展状況及び現状を 明らかにすることが重要と考える。また、豊富な歴史的資源を持ち、 巨大都市全体の保全と急速な開発との両立を試みる事例として、今 後の発展途上国における都市保全の参考になると思われる。

近年の中国における都市開発と歴史的環境の保全に関寸る日本の 既往研究では、名城制度を対象とした葉華らによる中国の歴史的環 境保全制度の研究 ${ }^{2}$ 、西安、蘇州、烟台、ハルビン、上海等の各歷 史的都市を対象とした歴史的環境保全についての関連研究などがあ

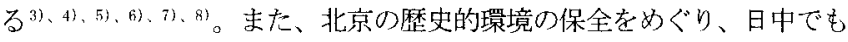
多くの関連研究が行われ泣汭、平永泉氏日)によって 90 年代末までの北 京における名城保全状況が紹介されている。本研究は北京における 歴史的環境保全制度の全体像と課題を明らかにするため、規制・計 画・事業三つの面から制度全体に注目したものである。3 章では、既 往研究の内容を参考に、90 年代末までの保全制度の発展経緯を整理 した。4 章では、それ以降の保全制度の発展動向之特徽について独 自の調查を行った。さらに、5 章では、現在の保全制度の構成にお ける保全刘象の四層体系の状況及び保全制度の課題を明らかにした 上で、规制・計画並びに事業に関連する行政部門・市民・専閶家な ど各主体の役割分析した。

\section{2 研究方法及び研究対象地の概要}

本研究では(1) 中国北京市注4) 政府各部門のホームページ、国家図書 館、設計単位（計画案の担当部門）で、保全制度の関連資料を収集 した。（2）規制・計画の運用及び事業の実施状況及び問題点について 実地調查を 2005 年 6 月、10 月と 2006 年 6 月に毎回 2 週間程度行った。 （3）99年以降の保全制度の発展状況及び保全実態に着目し、北京の歴 史的遺産保全や都市計画部門（市文物局、都市計画委員会）の担当 者、規制・計画の作成者及び事業実施地区の住民へのヒアリングを 通じて、保全制度の成立背景、形成経緯と各主体の関係を把握した。 分析方法としては、保全制度の発展経緯を踏まえて現状を明らかに するため、既往研究 ${ }^{2} ， 91 ， 10$ )を参考にした上で独自の時期分けを行っ た。また、都市全体（面）、保全地区（面）及び文物保護単位（点）の

\footnotetext{
* 新潟大学大学院自然科学研究科環境共生科学専攻 大学院生・修士 (工学)

** 新潟大学工学部建設学科 准教授・博士 (工学)
}

Graduate Student, Dept. of Environment Science and Technology, Grad. Sch. of Natural Science, Niigata Univ., M. Eng.

Assoc. Prof. Dept. of Architecture, Faculty of Engineering, Niigata Univ., Dr. Eng. 
いわゆる三層体系を基礎にして、有保護価值建築を独自に「網」と いう四層目と捉えて保全制度体系を整理した。

北京は、図一1より中央の地域が、旧城と呼ばれる明代からの古 都であり、多くの歴史的遺産が残っている。図一2 は旧城の区域及 び保護区の第一回指定を受けた 25 地区、第二回指定を受けた 15 地区 のうち5地区及び第 3 回に追加された 3 地区と拉幅の地区を示した。 また、第二回の残り10地区は図ー1に示した。表一1注6では旧城、市 区の旧城以外の地区、市域の市区以外の地区における国、市、区・ 県三級文物保護単位と保護区及びまだ文物にならず、文物調査に よって登録された歷史的建物、保護四合院沙》の数を示した。旧城内 に、単体保全対象及び保護区、特に保護四合院が集中している。

390 年代末までの歴史的環境保全制度の発展経緯（図一 3 )

3. 1 第 1 期 文物保護単位を中心とする単体保全の形成期 (1949 $\sim 1981$ )

北京は建国後の国家建設、60 年代後半からの文化大革命に上る社 会湿乱及び 1978 年からの経済改革という社会背景 ${ }^{(1)}$ を経て、1961 年 に国の「文物保護暫行条例」注8)により「点の保全」と言われる国、省 (直轄市)、市 (県) の指定文化財体系を定め ${ }^{22}$ 、をれを中心とした単 体保全を行った。その中には、50 年代初期に文物と古跡に対方る応 急保全と修繥、1958 年の一回目の市文物悉皆調查及び市級文物の選 定注9) 等が見られる。しかし、北京は50 年代に旧城を中心とする都市 発展の論争注10?及び 1958 年の[都市建設総体計画!に上り面的伝統景 観の価值を否定し、都市開発は旧城の城壁を含めた大量の伝統的建

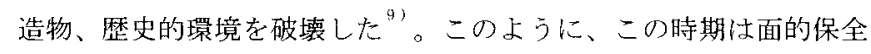
を考えず点的単体保全のみを行つた段階である。

\section{3 . 2 第 2 期 歴史文化名城保全制度による都市全体保全の草創期} $(1982 \sim 1989)$

1982 年には国は名城制度を創立し、北京を第 1 回国家歴史文化名 城として指定した。これを契機に、1983 年の「北京都市建設総体計 画」では、旧城の風貌や特徴を保全し、歴史的建造物に限らず周辺 環境も含めて保全すべきなどと提言した ${ }^{9 \prime}$ 。これにより、「北京市文 物保護管理条例」等法規の公布及び国家・市級文物保護単位の保全 範囲や建設制限地带の指定を行うことで歴史的建物周辺環境の保全 措置とした。また、80 年代後半、旧城内に增加した高層ビルに対し て、「北京市市区建築高度制限方案」等の幾つかの高さ制限に関する 規制が制定されたが、法律効力が弱く、90 年代に、違反が多く発生

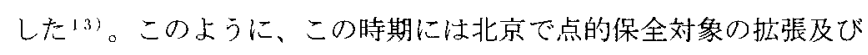
面的都市保全概念の形成が見られる。

\section{3 第 3 期 歴史文化保護区の設立による三層保全体系の草創期} (1990 1998)

1990 年以降、旧市街地の住環境を整備寸るため、老朽家屋を更新

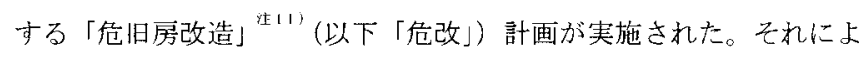
り、土地の有償使用制度 ${ }^{\text {ił12 }}$ や外国、私有資金の導入で不動産市場が 発展し、旧城内で都市再開発ブームが起こった。これに対応して、 1990 年、北京が旧城内 25 地区を歴史文化保護区に指定・公布したこ とにより都市全体、保全地区と単体の三層の保全体系が形成された。 1992 年の「北京都市総体計画（1991～2010）」にも、伝統中軸線、旧 城平面等 10 点の保全内容をめた歴史都市全体としての保全案が盛 り込まれた

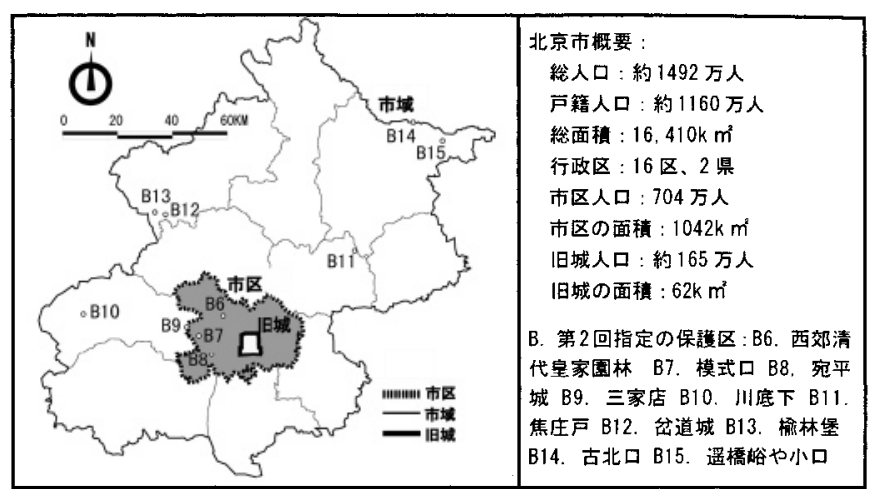

図-1 北京市市域及び歴史文化保護区の分布図

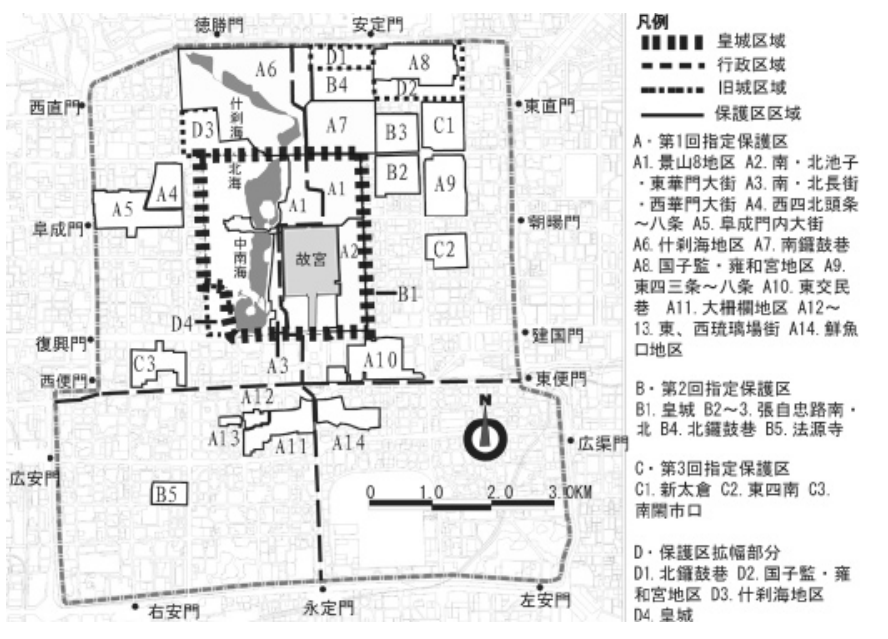

図-2 北京旧城区域及び歴史文化保護区の分布注5

表一1 北京歴史的遺産の保全現状（数字は件数）

\begin{tabular}{|c|c|c|c|c|c|}
\hline & 項H & | 1 日域内 & 市凶 & |本域 & 合部 \\
\hline & 韭界遗虐 & 2 & 1 & 3 & 6 \\
\hline & 今国文物保護単借。 & 34 & 16 & 10 & 60 \\
\hline & 访級文物保萑泣位 & 134 & 49 & 51 & 234 \\
\hline 市体保謢対象 & 区、紫級文物保讙单位。 & 115 & 59 & 327 & 501 \\
\hline & 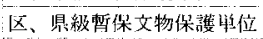 & 39 & 181 & 17 & 237 \\
\hline & 文物調查リスト & 478 & 310 & 1733 & 2521 \\
\hline & 保護阿命院院落 & 658 & 0 & 0 & 658 \\
\hline & 小部 & 1458 & 615 & 2138 & 4211 \\
\hline 保全地区 & 䄳史女化保護区 & 33 & $3:$ & 7 & 43 \\
\hline
\end{tabular}

て実施し、道路拡幅を止め、違法建築と工業建築を撤去、移転した。 また、伝統建築の修綘を行い、住民の住環境と伝統景観を改善した 13)。しかし、保護区では規制と計画がほぼ作成されず、具体的な実 施細則も各地区の範囲も確定されず、保護区制度は中身が存在しな い状態のまま放置され、そのため度々制限を無視した再開発事業が 行われた。1999 年までに、旧城内の牛街と城外頣和園路の二つの保 護区で再開発がなされ、地区の歷史的環境は完全に消失した汹13)。こ のように、この時期に三層保全体系が形成されたが、都市開発に比 べ保護区制度の整備と都市保全の赛施が行われず、中身を伴った制 度の策定が課題として残った。

\section{0 年代末以降保全体系の発展及び特徵}

4.1 第 4 期 三層保全体系の実行 - 強化と四層の萌芽期 (1999 2004)

（1）名城、保護区という面的な保全制度の具体化

1998 年、オリンピック開催資格の獲得によって、北京は、5 年以内 


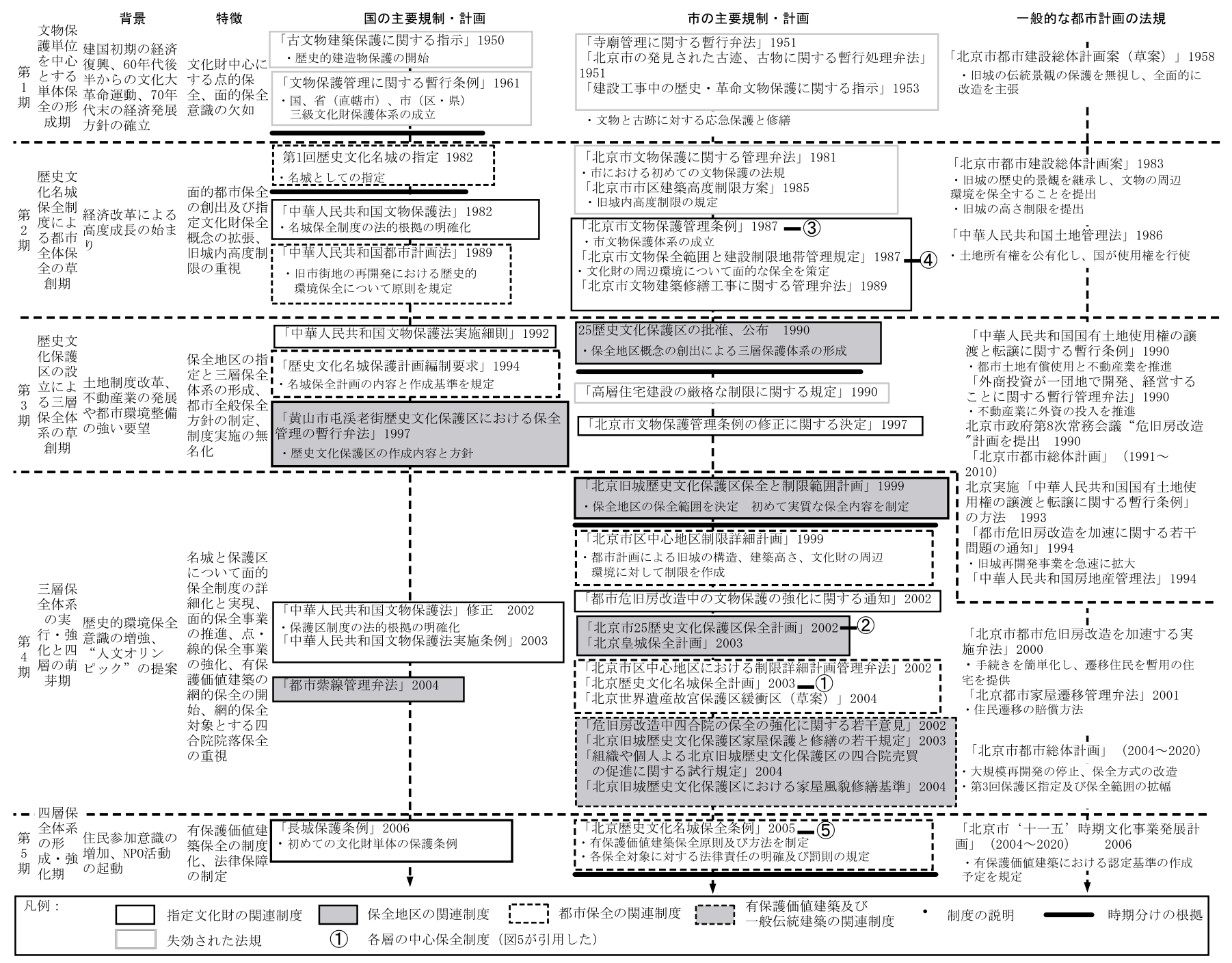

図一3北京における歴史的環境保全制度の発展

に旧城「危改」事業を完成すると発表した ${ }^{15 i}$ 。2 回目大規模再開発ピー クの到来に対応して北京は規制と計画の制度強化を始め、名城、保 護区に対して制度の整備は 3 期より奏質の段階になった。

1999 年にはリストの公布から 10 年目にしてようやく 25 保護区の保 全・制限区域の範囲を指定する保全計画が作成され、旧城中心地区 の街区・建物形態、用途等都市計画規制を規定した市区詳細計画も 作られた。2002 年に「25 歴史文化保護区保全計画」 ${ }^{16)} 、 2003$ 年に「北 京歴史文化名城・北京皇城保全計画」 ${ }^{17)}$ が制定され、マスタープラ ンとして地区の整備事業や修建性詳細計画 ${ }^{\text {(14) }}$ の基になった。保護区 の計画では地区のゾーニング、土地用途、歴史的建築の保護や利用、 城郭、城壁、水系、緑化、道路や胡同体系 ${ }^{\text {注 }}$ 的、建築高度制限や更新 方式、インフラ及び環境整備の実施等についてが明記されている。 保護区内の建物を建築の歴史的価值と建築風貌及び質から 6 種類に 区分し、それぞれに対応した整備を行うことになった ${ }^{\text {(16) }}$ 。(保護区計 画の完成により、保護区での事業の計画案の作成及び実施は統一さ れた参照基準ができ、保護区計画の完成前と比べると大規模再開発 よりも保全を重視寸る方向に改めて行くと考えられる。

名城計画は旧城区を保全重点とし、「三層」保全体系及び伝統文化、 商業などの無形文化財の保全を目的に作成されたものである。それ
でも、規定された都市保全の10 項目の内容に対灾する詳しい計画を 作成し、第 2 回 15 保護区及び保全範囲を確定した。2004 年の「北京 都市総体計画（2004～2020）」では、大規模再開発による旧城の歴史 的環境の破壊を認め、保全対象を拉大しつつ、保全制度の整備や保 全方法の改善を続けるとした。旧城内第 3 回 3 保護区の指定及び 4 保 護区保全範囲の拡大も行われた。これまでの全 3 回で指定した保護 区と単体保全地域を合わせ、旧城の約 $41 \%$ を占めることとなった。 また、高度制限 9 メートルの故宮緩衝区は2004 年北京市民に公布さ れ、2005 年 7 月 29 回世界遺産委員会で認められた。

また、国では、2002 年文物保護法修正案において保護区の法的根 拠が明確化された。2004 年建設部（日本の国土交通省に相当）は「都

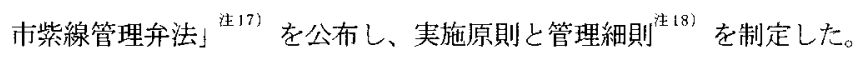
都市総体計画を制定する際には、保護区の範囲線を必ず設けること にした。これにより、各計画と規制の作成で保全対象の補充及び保 全地域の拡大を行い、実際の事業に詳細な現状分析と保全基淮を提 供したと言える。

\section{（2）面的保全事業の実行及び整備方法の険討}

25 保護区計画が作られた際には、保護区に適応する保全事業及び 整備方法の佮誩も実施された。事業の計画案の作成は都市計画委員 
会が設計部門を指定し、あるいは幾つかの設計部門でコンぺを行い、 最後的に行政、専門家チーム及びディベロッパーの意見を参考にし た上で、設計部門を決めて計画案を完成させる。2002〜2003 年に南 池子地区が初めて保護区の対象地として整備された。地区内の建物 の8 割ほどが取り壊され、2 階建ての「新四合院」に建て替えられる など、歴史的景観が大きく変わった。これと同時に、什刹海保護区 の烟袋斜街地区はディベロッパーを介入させず、小規模整備と呼ば れる市政府の投資と住民自らの修繥で地区の伝統商業と景観が蘇っ た成功例として見られる ${ }^{18)}$ 。2003 年には、保護区内の 6 地区 ${ }^{\text {湆 }}{ }^{199}$ の再 整備孛決定し、2005 年からこの中の鮮魚口・大䀳欄地区等の事業が 行われている。整備事業は先に住民を移転させ、建物を壊さず、文 物局の鑑定によって処置するという「人房分離」の方法を採用した。 (3) 点、線的保全事業の強化

2000 年 5 月、北京は 3.3 億人民元（1 人民元は約 15 円に相当）を出 資して白塔寺、国子監などの百箇所ほどの文物保護単位に対する修 繕事業を行った。2000〜2007 年、9. 3 億人民元 $(1949 \sim 1999$ 年の 3 倍) が修繥事業に使用される。また、線的保全として、中軸線・景観線、 歴史的河川の保全事業（伝統中軸線の南終点建築一永定門の再建、 歴史的河川一玉河の回復等）が行われている。名城保全計画では、 区級文物保護単位にも保全範囲と制限地带を確定すると規定した。

\section{(4) 有保護価值建築という「網」的保全の開始}

「有保護価值建築」とはいまだに文物保護単位にならず、ある程度 の伝統的な特徽と保護価值を持つ、あるいは真正性のある、又は比 較的に完全な形で歴史要素を伝える四合院と他の建築のことである (「北京歴史名城保全条例」 2 章 14 条)。

保護区計画で住、伝統四合院と他の有保護価值建築を含める「歴 史遺存」の保全を原則の一つとし、約 $9.3 \%$ 建築を保護類建築（有 保護(価值建築に相当) として選んだ ${ }^{16)}$ 。また、重要な近現代建築を 選定し、保全範囲と建設制限地带を設立するという規定も出された i7)。乙扎以外にも、2002 年 3 月から市文物局の古建築研究所は、旧城 の伝統四合院の調查を行い、2003 年 12 月までに計 3 回、658 籄所文 物保護単位以外の保護四合院を選定し、標識をつけ、リストを公布 した。保護区保全事業では、計画案に確定した有保護洒值建築を必 ず保存し、建物の状態によって修絴方法を制定する。規制・計画は まだ作成されていないが、有保護価値建築の概念を満たす多様な選 定の形が現れてきた。これによって、都市全体と保全地区の「面」的 保全と指定文化財単体の「点」的保全の間に、第四層目の保全と言 える多数の有保護価值建築の「網」的保全が開始されてきた。

（5）網の重点的保全対象となる四合院院落の保全

北京旧城の基礎を構成する四合院院落は各保全計画の重要な保全 対象となり、関連規制も多く作成された。2004 年 4 月には伝統景観 の保持上回復を目指寸ため、北京旧城歴史文化保護区家屋風貌修綁

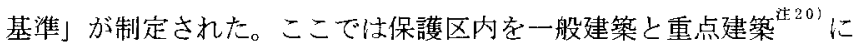
分け、四合院を中心に、家屋の屋根、壁、空、戸、装飾物及び色彩、 材料、形式などの要素に至る詳細な修緽基準が設定された。そのほ か、街路に面する建物に設置する屋外広告物、室外機などは景観を 乱さないようにという要求も出された。また、2004 年に制定された 「組織や個人による北京旧城歴史文化保護区の四合院売買の促進に関 寸る試行規定」により、初めて四合院の売買や貸貸、抵当、継承な どが認可された。税金減免などの優遇策が定められ、修復資金の調
達、四合院の活用・再生を促進するための施策が盛り込まれた。そ れから、伝統四合院に関する観光業の発展によって保護区内旅館、 レストラン等に転用される四合院が増えている ${ }^{19)}$ 。また、保全事業 では、保護区計画の建築分類索参照し、四合院を歴史的価値及び質 から再調查し、修綁、改筑、再建等の整備方法を選択する。

\section{2 第 5 期 四層保全体系の形成・強化期 (2005 )}

\section{（1）名城保全における法的効力の強化}

5 期では、4 期に作成された保全制度を引き続き、その上で、より 一歩法的効力の強化を行った。2005 年には、「北京歴史名城保全条 例」(以下名城条例) の公布により北京の歷史的環境に対して高い法的 拘束力が向上される。この条例は初めて有保護価值建築を三層保全 に入れ、四層保全内容を規定することとなっている。また、保全計 画の作成、運用を担当する各部門の貴任者を明確にし、計画の違反、 また、職責の任を果たさない等の行為に詳細な厳しい制限や罰則を 規定する。特に有保護価值建築に対する取り壊し、改築、增築行為 及び所有者、管理者、使用者は必ず保護・修繕の義務急負い、違反 した場合は 10 万〜 20 万人民元の罰金が課される。このような重い罰 金が設定されたことは保全の根拠と保障を強化したと考えられる。

\section{(2) 有保護価值建築の制度化}

今現在、北京都市計画委員会と都市計画設計院は「北京市優秀近 現代建築保全計画」（文物保護単位にならない近現代有保護価値建築 を対象）を作成途中である。2006 年10月に公布された「北京市“十 一五”時期における文化事業の発展計画」で佶、今後「北京市有保 護価值建築の暫時認定基準とプログラム」の研究・作成を行うべき とされた。このように、4 期より、建築の選定のみに限らず、名城 条例による保全方法の設定、一部有保護価値建築の保全計画及び統 一の認定基準等の制定によって有保護価値建築制度の整備、選定対 象の充実及び名城条例の実施と監督は発展を遂げている。

5 保全制度の構成における保全対象の体系、課題及び各主体の役割 5.1 規制・計画及び事業による保全対象の体系と保全制度の課題 (1) 一層目の都市全体保全 (図一4)

都市全体保全仗、歴史的都市空間の特徽により、旧城に保全重心 を置くことになっている。その中では、140保護区を含め、故宮を 中心とする皇城が特別な保護対象として扱われ、保全計画が制定さ れた。また、消失した歴史要素の復元（城門・櫓、河川・湖等）、現 存歷史的要素の保全（城門・橹、河川・湖、中軸線の節点景観、対 景建築注211 等) 及び制限（建築高さ・色彩と屋根形式、中軸線及び景 観線・対景建築周辺の高さ）等（図一5）の手段により、旧城特有 の構造、歷史水系、眺望景観、緑化、色彩等を含めて保全するとさ れる。保全計画は具体的な保全対象上方法を確定し、現存の歴史的 景観の保全及び新たな景観形成を目指している。また、伝統商業、 芸術等の無形文化財も保全対象としている。しかし、課題は各伝統 要素を保全する一方で、保護区以外の伝統建築及び四合院はまだ保 全対象とされていないことである。これは、保護区外に質の悪い伝 統四合院が比較的多く、全部の修縉・保全が不可能であるため、大

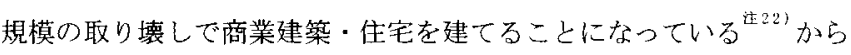
である。激しい再開発に対念して、質がより良い四合院を残して修 繕し、それを中心とした投資者の収益性が高い新四合院地区（旧城 内の四合院の価格が高騰している）を作り、新築への景観規制で町 


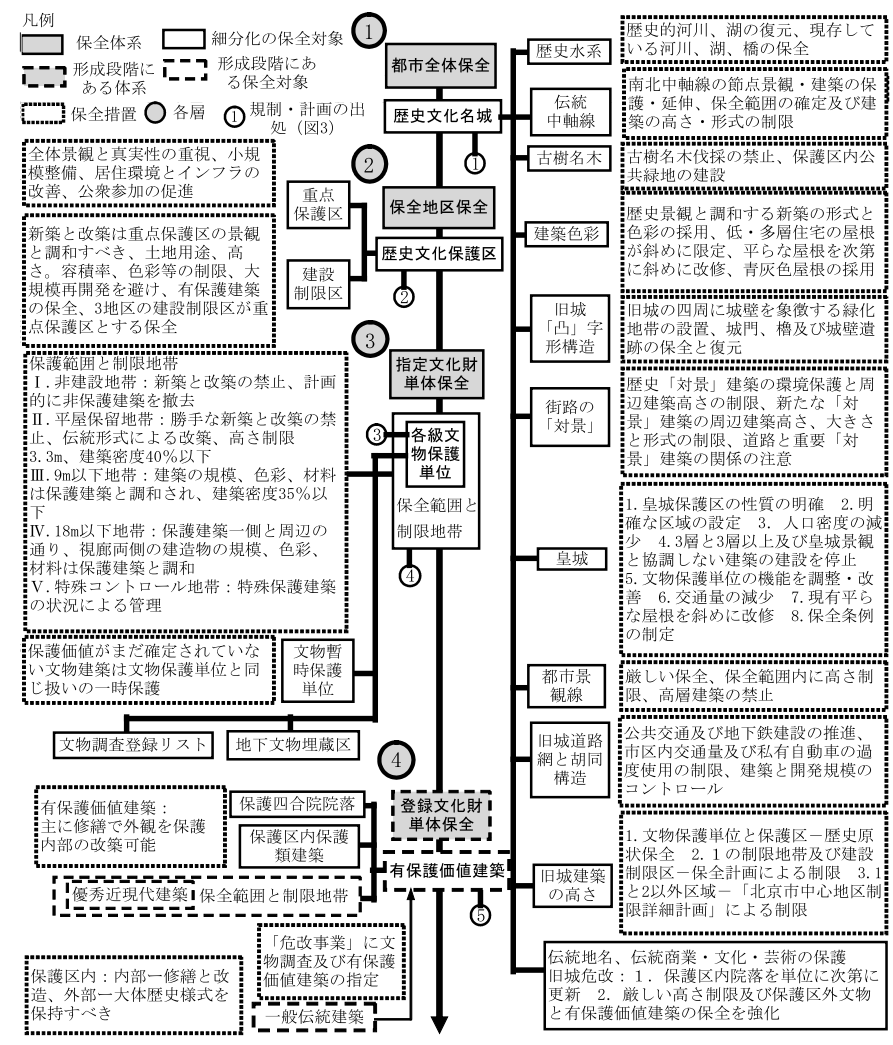

図一４規制・計画及び事業による保全対象の体系

並みの伝統景観を継承できることが最低限の手段であると考える。

\section{(2) 二層目の保護区保全}

重点保護区と建設制限区に分けられ、重点保護区は地区全体の固 観やオーセンティシティの保護、小規模整備と市民参加の促進を原 則としている。建設制限区は相対的に緩い保全であり、重点保護区 との調和、土地用途、高さ等の制限及び有保護建築の保全を重視し、 また、二つとも大規模再開発の抑制を示している。

しかし、課題としては「大規模」の概念が噯昧で、建設制限区で 新築と改築が可能であるため、厳しい制限が実行できない。保護区 計画の道路計画では1999 年「北京市区中心地区制限詳細計画」に設 定された道路紅線を参照せず、伝統景観を破壊しないという目標 ${ }^{16 .}$ が規定されたが、旧城内の交通泚滞を解決するため、多数の道路桩 幅が実施された。2004 年、伝統中軸線にある旧鼓楼大街は $10 \mathrm{~m}$ から $30 \mathrm{~m}$ に、2005 年、大柵欄地区の煤市街が $25 \mathrm{~m}$ に搪幅され、鮮魚口地区 にも $25 \mathrm{~m}$ の東鋪路が新しく作られた。多くの伝統建築が取り壊され、

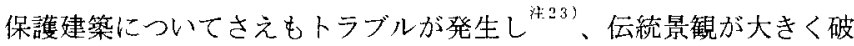
壊された。保護区内では、大量の取り壊しを伴う大幅な道路拡幅及 び新設を制限しなければ、保全計画の原則である「全体景観と真実 性の重視」が実現できないと考える。

保護区の再開発事業（南池子、鮮魚口地区等）に扔いて、政府は ディベロッパーの資金を導入し、商業利益を優先しがちで、住民を 移転させ、地区の一部を高級住宅区及び商業建築に転用することが あった。移転住民は低価格の補償、郊外に移転後の就職困難、生活 不便 $^{20)}$ 等の問題による不満を漏らし、紛争が多く、私有住宅の住民 と合意がないまま伝統的四合院を撤去した等の問題も見られた。 2006 年、住民の苦情を対応して、政府は一部の低価格「経済適用房」 を移転住民に提供した ${ }^{\text {注24) }}$

\section{(3) 三層目の指定文化財の単体保全}

国、市、区・県級文物保護単位が中心となる。周辺環境は保護単 位を中心にし、I からVまで輻射状の 5 つの保全範囲や制限地带（図 ー4）在設定した。それによって建物の高さ、建設密度等老明確に 制限している。また、区、県級の歴史的建造物は保全価值の確認が 完了するまでの期閒、「文物暫時保護単位」として保全され、文物調 查リス卜に登録されるものも文物保護単位に追加される前は取り壊 しができない。しかし、全ての文物保護単位に $\mathrm{I} \sim \mathrm{V}$ の保全範囲と 制限地带が設定されているとは限らず、図ー5の(1)示すように設 定されない文物保護単位も多く存在している。

\section{(4) 四層目の登録文化財体系}

有保護価値建築は保護四合院、保護区内の保護類建築、優秀近現 代建築という選定形式が見られ、主に外部保護、内部改築吢可能で あるというより緩い保全がある。日本では登録文化財建物が届出制 であるが、北京では、有保護価值建築の所有者でも法律の許可を得 ず取り壊しや增・改築及び建物の名前変更を自由に行えない。所有 者も修繬、保全の義務を行わないといけない。登録文化財体系はま だ整備の開始段階であり、選定数が少なく、統一の選定基準もなく、 整備地区以外では修繥事業も見られない。

\section{(5) 一般伝統建築の保全及び課題}

四層以外の一般伝統貄築については2002 年の「危改中四合院の保 全强化に関寸る若干意見」によって、旧城内の建設、「危改」事業前 には、文物調查を行うこととなっている。認定される有保護価値建 築のみならず、院落の構成が比較的に完全であり、建築構造の状態 が良い一般伝統建築及び集中的に分布する四合院群落等は、元の場

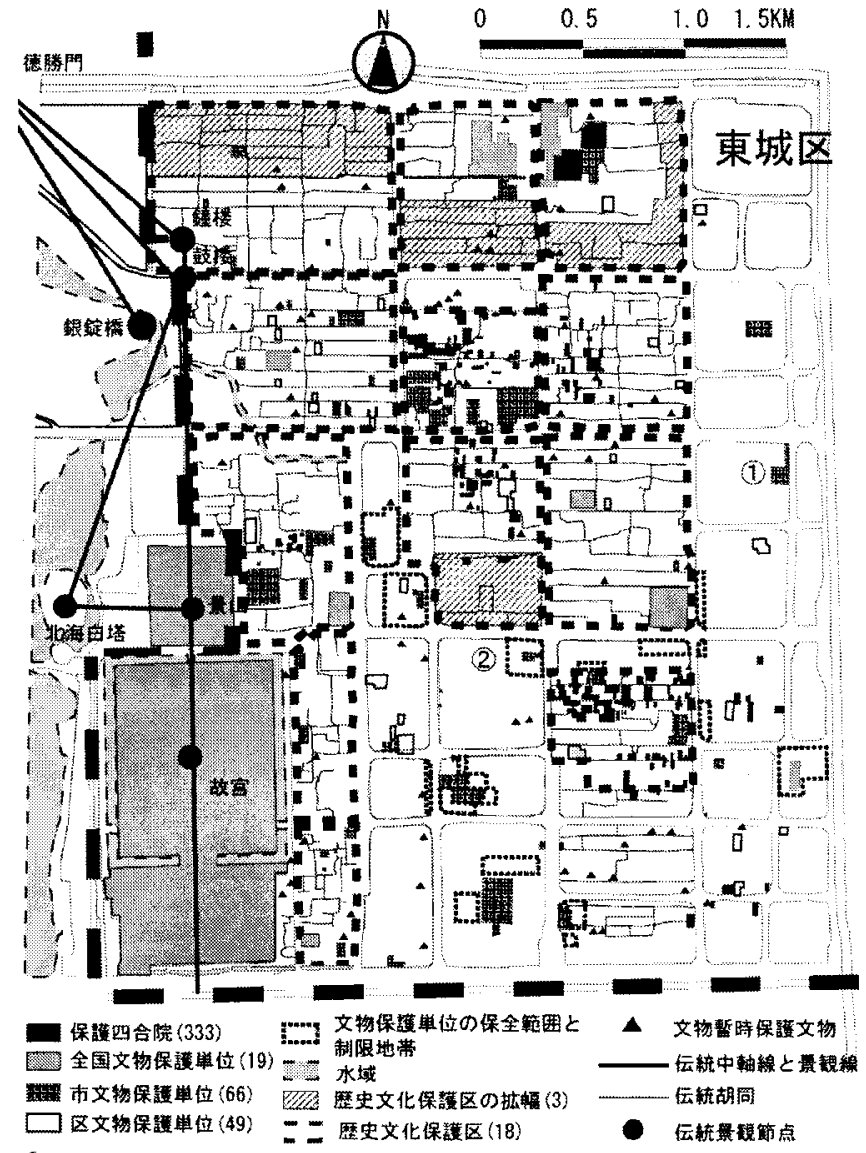

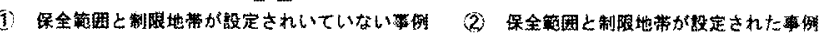

図一 5 各保全体系に関する保全状況の実例一東城区 


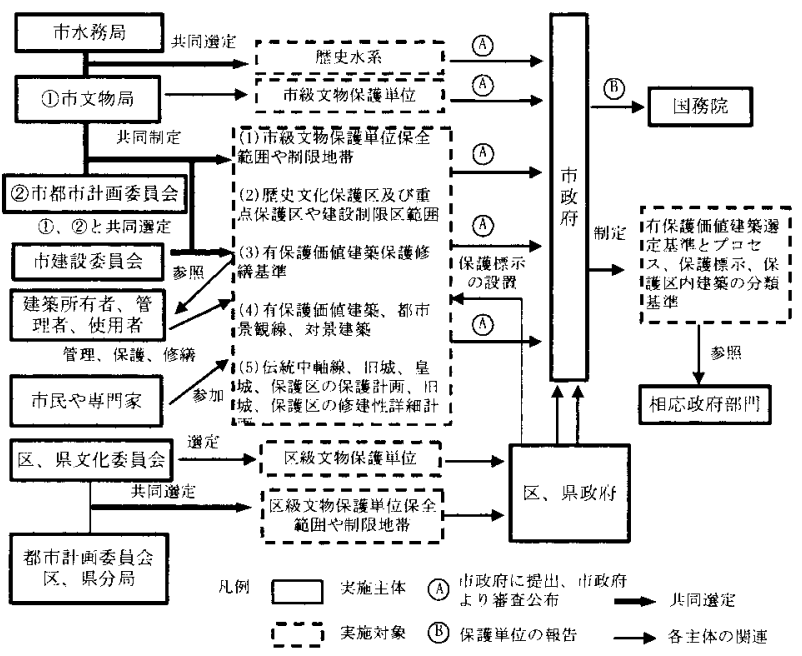

図一 6 規制・計画の作成・運用に関する主体の役割 ${ }^{\text {法28) }}$

所で保全すべきと規定された。しかし、実際で㤌有保護価值建築以 外の一般伝統建築は都市計画委員会の許可を得た上で新築すること が可能であり、一般伝統建築の違法破壊行為に対して、藅則もない ため、保護区でも、事業により大量の一般伝統建築を取り壊すこと があった。北京の保護区は日本の重要伝統的建造物群保全地区と比 ぶて、一般伝統建筑については手厚い保護がなされていない。

また、一般伝統建築は主に国有または公有であり、再開発によっ て移転される恐れがあるため、自らの資金で修絟するという住民の 熱意が欠乏し、修䜌基準の実現が難しいという状況が見られる。

5.2 法規・計画及び事業における各主体の役割（図一6）

(1) 各行政部門の関係：「文物保護法」によって国、省（直轄市）、市 (直轄市の区・県)における三級の文物保護単位はそれぞれの文物局 で認定し、それぞれの政府が番査・公布し、上級政府一報告して記 録することとなる。また、文物保護単位の保全範囲の選定は文物局 と都市計画委員会 ${ }^{\text {(125) }}$ が担当し、国級は省 (直轄市)により、省、市 級は同級の担当部門により選定される。国級の場合は省（直轄市） 文物局が国務院文物行政部門人報告して記録に載せると規定した。 また、歴史水亲の選定は市水務局と文物局、有保護価値建築修繥基 準の制定は市文物局、都市計画・建設委員会が行う等、各規制・計 画の制定は主に市文物局と都市計画委員会を中心に各行政部門の協 力で行われる。しかし、多機関の権限分散により管理範囲が不明確 21) であり、都市計画委員会の建設決定（特に一般伝統建築の取り壊 し）に対して、文物局の権限が弱い等の問題点がある。

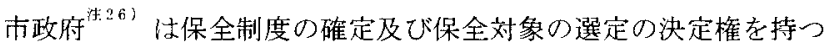
と同時に、保護区内建築の分類上保全基淮、有保護建築選定基準等 の制度基整を作成し（専門家チームや各部門役員の協力で作成し、 市政府が会議で決定する)、各部門に提供する。また、区・県政府は 区級保護対象の決定権の他に、有保護価值建築標示の設置及び保護 区の修建性詳細計画、家屋の保全・修繥計画の制定と実施も行う。

文物建築及び歴史的河川、緑化等の保全事業は文物局等の関連部 門が行う一方で、保護区の事業は整備地区がある区政府の関連部門 を通して、投資者が申請を都市計画委員会に提出ずる。文物局、園 林と住宅管理部門は建築の質等の現状調查を実施し、計画案の修正 も各部門の審査を受ける。最後は、完成案を市政府に提出すること になる。しかし、投資者としてのデベロッパーの意見が計画案の作
成と修正に過大の影響を与えるという指摘もある。

（2）専門家の役割：北京では、保全事業において専門家の協力は重視 されている。1981 年には、学者、建築家及び行政管理者 30 人以上の 文物古跡管理委員会が設置され、市政府の文物保全研究・審査・管 理事務に協力した。2 5 保護区の保全計画を制定する際に、都市計画 委員会は「歴史文化名城保全専門家庫」を設立し、この専門家の審 查チームが保全計画の修正を行った。また、重要な規制、名城、保 護区等各計画及び事業の計画案の作成、修正や旧城内の建設項目の 審查は専門家審議会の諭証上同意を得ることが必要となった。これ は法律の強化により専門家の役割老確立させ、大規模再開発の発生 を抑制していると考えられる。ただし、一般伝統建築の大規模な建 て替えを主張する専門家の意見がより多く採用されるといら指摘が あり、専門家審議会の公正性がまだ明らかにされていない。

（3）市民とNPO の役割：2004 年の「都市紫線管理弁法」で初めて保全 計画の制定及び修正は市民の意見を求めるべきと規定された。名城 条例は再びそれを強調し、保護建筑の破壊行為を市民が訴える権利 も明確にした。ここでは、旧城内の「危改」事業では事前に住民の 意向調査を行い、インターネット・事業実施地等で作成中の詳細計 画案を公示し、意見を求めることになっている。また、個人、市民 団体の自発的保全活動（四合院の購入・再生、ホームページの作成 及び再開発中の監督活動等) が見られる。旧鼓楼大街と鮮魚口地区 等再開発事業に対する反対運動として、NGO、学者、民主党派を含め た市民代表が世界遺産大会及び市政府に意見書を提出したことも あった。しかし、市民参加の增加及び行政がそれを重視する傾向が ある一方で、事業前の情報公開と個人単位の意見収集という象徵的 参加は行われるが、計画案の修正について公聴会のような実質的参 加はまだ見られず、市民意見への対空が不透明等の問題点がいまだ に残っている。また、事業地区の住民に対しての経済補償により投 資者への住宅使用権の譲渡を促している。しかし、経済補償は市場 の価格より大分小さいため、移転住民の利益が損なわれる。そのほ か、NP0 法人の動きも始まっている。代表として北京文化遺産保護中 心 ${ }^{2}$ が、歴史文化遺産の保全・宣伝・教育及び行政、学者、市民 の連携を目標に活動している。専門家の出席を請い、行政、市民に 保全知識、法律の講義及び助言を行っている。しかし、活動の経費 のほとんどが外国組織から寄贈されたもので、組織も小規模である。 このように、現在市民参加及びNPO 活動は単独で活動しているもの が多く、行政との連携はまだ不十分である。

\section{6 結論}

（1）建国から90 年代末にかけては、(1)文物保護単位が中心の点的単 体保全、(2)名城の選定等に上る都市全体の面的保全の開始、(3)保護 区選定という地区レベルの面的保全による三層保全体系の創出とい う3 期で発展した。しかし、保護区制度はまだ不十分であった。

(2) 第 4 期では、単に指定だけでなく、具体的な計画や規制の制定に より面的保全制度が強化された。また、保護区に招いて保全事業が 奏行され、点、線的保全事業の强化も行われた。有保護価梿建築と いう「網」的保全が開始され、四層目の萌芽が見られる。

（3）第 5 期はそれまでの国の制度のみでなく、北京独自の名城保全条 例によって行政責任の明確化、罰則の制定を行い、法的拘束力が向 上した。特に、有保護価值建築の外観变更などが許可制になり、「網」 
的保全が強化された。四層体系がほぼ確立したと言えよう。

（4）従来と比べれば、四層保全体系全体に扔ける制度の充実がなされ つつあるが、まだ次のような課題が存在している。(1)都市保全をす るとしながら、奏際は保護区外の伝統住宅地は対象外である。(2)保 護区内でも一部の伝統建築しか保全されておらず、住民の反対にも 関わらず、道路拡幅・新設による歷史的環境の破壊が強行されてい る。(3)文物保護単位も保全範囲と制限地带が設定されないことが多 い。(4)有保護価值建築の「網」的保全はまだ開始段階で、数が少な く、統一された選定基淮もない。

（5）保全制度の作成と実施は市政府主導であり、文物部局と都市計画 部局が協力して実行している。近年は名城条例により保全事業の審 查過程に尃門家の関与が義務付けられ、市民参加も導入されている。 しかし、保全事業番查の透明性・公正性、市民の実質的参加などの 上で課題がある。市民組織による保全活動も存在するが、行政の連 携はとれていない。特に、保全事業前の公聴会等、より実質的に市 民の意見を反映させる場を作るべきと考える。

\section{注}

注 1) 1992 年の「北京都市総体計画」は「歷史名城、歴史文化保護区と文物保 護単位の三層」保全体系から全面的に歴史的環境を保全すると規定した。 歴史文化保護区の定義は「ある歷史時期の伝統風貌、民族特色を持つ街区、 建築群、村鎮であり、名城の重要構成である」(文献 17)。そして、2002 年 都市計画法で歷史文化街区と命名し、2005 年「北京歷史名城保全条例」で、 秋史文化街区と名前を統一した。本論では歴史文化保護区を使っている。 また、保全対象に関する固有名詞以外の中国語を全て日本語訳の表現を 行った。例えば、「規劃」「城市」を日本語の「計画」、都市」に統一した。 また「保護」は「保全」に統一したが、建築単体は、「保護」を使用した。 注 2) 北京は1990 1999 年の10 年間に 436 万 $\mathrm{m}^{2} 、 2000 \sim 2002$ 年の3 年間に 443 万 $\mathrm{m}^{2}$ の老朽化住宅省取り壇した」(北京文物局情報中心 HP. 2007.5.31 時 点)

注 3) 北京に抢ける関連研究では、80 年代以後與良鏞氏による清華大学の一連

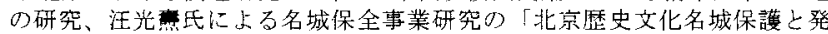
展」、日本では藤川らによる四合院の空間と住居状沅の研究、鄧奕らの北京 内城街区構成の研究が行われている。

注 4) 中華人民共和国憲法によって、中国の行政区域は省級、地級、県級、詼 級の行政階層に分けられ、北京は直䡚市として省や自治区と同じ省級行政 区であり、下に16 直轄区や2 県がある。

注5)この図汢文献 17 墓礎にして作成した。

注6)表中のデー夕は2004 年「北京歴史文化名城・皇城保全計画」から引用 た (2002 年の統計)。2005 年 10 月現在は市級文物保荽単位が 327 、区・県䄲 文物保護単位が 568 篁所になっている(北京文物局 HP.)。

注 7) 北京の代表的で伝統的な住居㥞式で、中庭を围んで四つの房（建物棟） が建ち、四合院の1構え存院落と呼んでいる。

注 8)「条例」は国務院及び省級人民代表大会が憲法及び法律に基づき、議決 を経て制定される法規の一種である。

注9）現在まで、北京市は、1958、1983、1999 年 3 回の文物悉皆調查を行い、 1959、1979を含めて7 回市級文物保護単位を指定した。（文献 12）

注 10)50 年代末、政府你思成らの「旧城を保全し、西郊外で新都心を建設す る」という提案を否定し、旧城を中心として都市を発展させると決めた。

注 11 )危旧房改造」とは旧市街地の住居環境を改善するため、老朽化家屋が 集中した地区を指定し、政时は税金兔除などの優遇政策によって、不動産 業者の資金を介入させ、地区の再開発を行うことである。

注 12) 土地有償使用制度 : 国上国有土地使用者の経済関倸を調整寸る制度(门土 地管理法」第 2 条)、実質の表現は国は国有土地使用者方国有土地使用権利 の獲得と使用時に土地使用者加的もらった土地経済利益。(文献 14)

注 13) 1990 年代の再開発によって牛街と城外臨和園路で㤬歴史的環境が完全に 破壊され、25 保護区のリストから消された。1999 年、「北京旧城歷史文化保 護区保全と制限範囲計画」に壮鮮魚口、東四三条〜八条の二地区が補充さ れ、保護区は 25 に扈った。

注 14) 中国の都市計画は総体計画、分区計画と詳細計画の三段階があり、詳 細計画は控制性詳細計画 (日本の地区詳細計画に相当歹る) と修建性詳細 計画(事業区域における都市計画事業の実施プランであって、日本の都市 計画案に相当する)に分けられる。

注 15 ）胡同体系は四合院院落及び胡同によって構成された地区の構造である。 注 16 ）建築の老朽程度によって建築質を「良い小、谱通小、要いに、伝統的 景観及び歴史価值によって「各級文物保護単位」、「支る程度の歴史文化価 值を持つ伝統建築や近現代建築」、「一般伝統建築」、「伝統景観と調和寸る 建築」、伝統景観と調和しない建築」に分ける。二つの面を総合的に考慮 した上で、建築の保護方法によって「文物類」、「保萝類」、「改善類」、「保 留類」、「更新類」、「沿街装飾類」と分類する。

注 17) 都市計画における各種用地の境界線は図面で色分けされている。都市柴
線とは国、省、市等各級保護区の境界線である。ほかに、都市藍線（地表 水系)、都市緑線(緑地範囲)、都市黄線(社会基盤施設用地) 等がある。 注 18）実施原則と管理細則は法規が実施する参照基準及び運用する規範と制 限のことである。

注 19) 白塔寺、鮮魚口、大柵欄、煙袋斜街、三眼井、王河の 6 地区が試験地区 として市政府に選ばれた。

注 20$)$ この法規では、重点房屋老保護四合院院落、中式楼、西洋楼等の建築上 定義した。一般房屋は、一般四合院を含めて修縉基準を規定した。

注 21 ) 対景建築は良い景観を形成するための道路及び景観線の雨倒に建てられ る建築である。

注22) 2005 年末で、保護区以外では金宝街、米市胡同、文華胡同等多くの伝統 的住宅地区が大規模に再開発された。

注 23）市民は鮮魚口地区再開発事業中に 6 筒所の区級文物保護単位上暫保単位 が取り壊されていると指摘したが、文物監察組織は取り壊しでなく修綞と 移築であると主張した。http://bbs.oldbeijing.net/dispbbs.asp? boardID $=25 \& I D=5273 \&$ page $=3(2007.5 .31$ 時点)

注 24)「経済適用房」は中国の低利潤で低収入階級に住宅を提供する福利政策。 注25）1950 年代から、北京の文物保護は主に市文化教育部門により行われて きたが、女物局は1978 年に文物保護部門として独立した。1953 年、北京都 市建設委員会が成立し、1970 年代に都市計画管理局（城市規劃管理局）、 2000 年 2 月に都市計面委員会に改名した。

注 26 ) 市政府は市長、副市長、秘書長、市政府各部閏の主任、局長等で構成 られる。一般法規、政府令については、関連部門が作成し、南政府常務会 議で審查・批准している。(「北京市人民政府工作規則」)

注 27) 北京文化遺産保護中心性1999 年に現在の国家文物局の法規処(処は日本 の課に相当) 処長何戌中氏により創立し、2003 年にNPO 法人として登録し た。現在は行政、学生ボランティア等をメンバーとする。

注 28) ここでは、文物保護単位及び保全範囲と制限地带の内容を「北京文物 保護条例」から、他の内容を「名城条例」から引用した。また、図 4 にあ るが、图6に示されない保全対象流、注ぼ市文物局のみが担当する。

\section{参考文献}

1) 焦怡雪 :「コミュニティ発展一北京旧城歷史文化保護区や改善の可能性手 段」，清華大学博士論文, 2003

2）葉華，浅野聡，戸沼幸市：「中国における歴史的環境保存のための歴史文化 名城保護制度に関する研究一名城保護制度の枠組みの整備過程の特徽と課題 一」, 日本建築学会計画系論文集第 494 号, pp. 195 204, 1997. 4

3）荒川朱美，大西國太郎，西尾信広：「中国西安市・德福巷伝統的民居地区に 招ける保存上再生に関吉研究」, 日本都市計画学会第 30 号, pp. 457 462, 1995. 12

4) 王郁, 三村浩史，東樋口護，橋本清勇：「水楖都市・䔡州に打ける都市開発 と歴史的空間形態の保存一 $1980^{\prime} \mathrm{s}$ 以降の改革開放期についてー」，日本都 市計画学会第 33 号, pp. $271 \sim 276,1998.11$

5 ) 林宜徳, 畔柳昭雄：「中国山東省烟台书における歷史的建造物の保護制度に 関寸る研究」，日本建築学会計画系論文集第 576 号, pp. $223 \sim 230,2004.2$

6) 呂禾, 岡崎篤行, 樋口忠彦: 「ハルピン市における保護歴史的環境再整備事 業の赛態一中央大街、聖・ソフィア教会堂を対象上して一」, 日本建築学会 技術報告集第 16 号, pp. $227 \sim 230,2002.12$

7) 呉禾, 樋口忠彦, 岡崎篤行：「ハルピン市の旧市街地再整備事業における歴 史的環境保護行政の役割」, 日本建築学会計画系論文集第 552 号, pp. 223 $230,2002.2$

8 ）㜊松，西村幸夫：「上海外灘歴史地区の景観保全計画に関寸る研究」，日本建 築学会計画論文集第 496 号, pp. $125 \sim 130,1997.6$

9) 平永泉：「建国以降北京旧城改造や歴史文化名城保全」(「建国以来北京的旧 城改造与歷史文化名城保護」)，北京規刯建設，pp. $25 \sim 28,1999.5$

10）西村幸夫：「アメリカにおける1960年代前半までの歴史的環境保全制度の 展開」，日本建築学会計画系論文集第 444 号, pp. 105 114, 1993. 2

11) 大西國太郎，朱自宣：「中国の歴史都市これからの景観保護と町並加の再生 人, 鹿岛出版社, 2001.7

12 ) 銭威, 岡崎篤行:「北京における歴史的環境保全制度の変遷」, 都市計画報 告集 N0.5, pp. $5 \sim 8,2005.6$

13) 方可：「当代北京旧城更新」，中国建築工業出版社, 2001

14) 朱青, 小林重敬，高見沢実:「北京市中心地区に招ける土地利用転換に上る 再開発の仕組みに関する考察」，日本都市計画学会学術研究論文集第 36 号, pp. $181 \sim 186,2001$

15）孔繁峙：「危房改造方式と伝統四合院保護」，北京市文物局 H. P. , h t t p : / www. b jww. gov. cn $/ 2004 / 12-7 / 3717$. shtm1 (2007.5.31 時点)

16)「北京旧城 25 歴史文化保護区保全計画」(「北京旧城 25 歴史文化保護区保 護規劃」)，北京市規劃委員会，中国燕山出版社， 2002

17)「北京歴史文化名城・北京皇城保全計画」(「北京歴史文化名城・北京皇城保 護規劃」)，北京市規劃委員会，中国建築工業出版社，2004

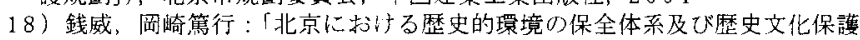
区の再開発に関する研究」，日本建築学会北陸支部大会 第 36 回，pp.181 $\sim 186,2006$

19) QianWei, AtsuyukiOkazaki: ГA Study on Framework of Historic Conservation District Systrm and Actual Condition of the Reutilized Historic Architecture in Beijing $\rfloor$, The Conference of Asian City Planning 2006 Proceedings, pp. $69 \sim 74,2006,12$

20) 張傑，陳珊珊：「理想と現実の消からの脱却」，「東アジアに㧍ける首都の近 代化と都市保存」国際シンポジウム, pp. 132〜137, 2006.12

21 ) 阮儀三，王景慧：「歴史文化名城にお打る保全理論之計画」(「歷史文化名城 (保護理論与規劃」), 同済大学主版社, 2002 